\title{
BELAJAR: PROSES MEMBANGUN KEMAMPUAN UNTUK MENGENDALIKAN MASA DEPAN DENGAN BAIK
}

Oleh:

Meilanny Budiarti Santoso

\begin{abstract}
ABSTRAK
Manusia memiliki pilihan hidup untuk menentukan jalan hidupnya, dalam rangka mencapai visi yang diperjuangkannya. Namun, ironisnya sebagian besar manusia menjalani hidupnya tanpa visi dan misi yang jelas. Hal tersebut berdampak pada konteks lingkunan kehidupan mereka di masingmasing lokus mereka, bahkan akan mempengaruhi lingkungan sosial mereka. Bahkan kehidupan dan keberhasilan organisasi seringkali sangat dipengaruhi oleh cara pandang dan tindakan para anggotanya. Seseorang haruslah mampu berjalan dengan baik pada jalan yang menuju pada arah yang benar. Itulah yang disebut dengan visi kehidupan. Hidup dengan visi, dan hidup untuk memperjuangkan visi. Begitulah cara jika orang mau panjang umur, dalam arti sehat, bugar, bersemangat, dan berprestasi; dengan catatan, visi tersebut harus menyangkut - dan untuk kepentingan memberi manfaat bagi orang banyak (Wibhawa, 2016). Rasa kesalingtergantungan dalam relasi sosial membuat seseorang menaruh perhatian terhadap apa yang akan terjadi pada orang lain, suatu hal yang penting untuk membangun hubungan yang saling menghormati dan saling mempercayai. Semua ini akan menolong seseorang untuk mengatasi keberagaman, membina kerjasama kreatif, dan menyelesaikan konflik dengan damai. Ini adalah ranah kecerdasan interpersonal
\end{abstract}

\section{PENDAHULUAN}

Semua orang ingin sukses dalam hidupnya; sukses dalam belajar, sukses dalam bekerja, sukses dalam berkeluarga, sukses dalam berbisnis dan ujung-ujungnya ingin hidup bahagia. Tentunya tak hanya bahagia di dunia, tetapi juga bahagia di akhirat. Untuk itu, seseorang melakukan berbagai usaha sebagai bentuk ikhtiar mereka dan menentukan pilihan dalam bersikap dan melakukan berbagai bentuk pilihan tindakan dalam perjalanan hidupnya.
Banyak orang bekerja keras dalam hidupnya, bahkan bekerja sepanjang hidupnya; orang belajar dengan keras, menuntut ilmu tiada henti, memilih dan menentukan tindakan tertentu untuk menekuni suatu bidang usaha, mengasah keterampilan pada suatu bidang keahlian tertentu, memilih pekerjaan yang dipandang akan memberikan kepastian pendapatan, memilih tempat tinggal yang layak, memilih teman yang dirasa dapat meningkatkan kualitas mereka, memilih lingkungan sosial yang dipandang kondusif, dan berbagai macam pilihan 
lainnya dalam kehidupan. Dalam konteks organisasi ataupun lembaga, seorang pemimpin tentunya memilih dan menetapkan strategi pada lembaga yang dipimpinnya, menentukan kebijakan lembaga, menetapkan sistem lembaga, memilih staff yang baik, membuat struktur organisasi untuk mencapai keberhasilan lembaga.

Untuk memperoleh hasil yang diharapkan tentunya sudah barang tentu memilih dan menentukan berbagai hal yang menurut pandangan kita benar saja tidak cukup. Seseorang haruslah memiliki niat yang benar dan dalam melaksanakannya pun harus dilakukan dengan cara-cara yang benar. Menetapkan arah yang benar itu perlu, namun belum cukup. Seseorang haruslah mampu berjalan dengan baik pada jalan yang menuju pada arah yang benar. Itulah yang disebut dengan visi kehidupan. Hidup dengan visi, dan hidup untuk memperjuangkan visi. Begitulah cara jika orang mau panjang umur, dalam arti sehat, bugar, bersemangat, dan berprestasi; dengan catatan, visi tersebut harus menyangkut - dan untuk - kepentingan memberi manfaat bagi orang banyak (Wibhawa, 2016).

Untuk mencapai masa depan yang cemerlang, maka pendidikan adalah kuncinya: membangun pendidikan dengan arah yang tepat dan dijalankan dengan cara yang tepat pula; pendidikan untuk membangun masyarakat Indonesia yang warganya cerdas serta berkarakter baik dan kuat; dan tentunya pendidikan dalam hal ini menunjuk bukan hanya pada proses pendidikan yang diselenggarakan di sekolah-sekolah ataupun di kampuskampus saja, melainkan pada pendidikan dalam arti luas, yaitu: pendidikan di rumah, di sekolah, di masyarakat, melalui berbagai media.

\section{PEMBAHASAN}

Melalui pendidikan, setiap civitas akademica yang terlibat di dalamnya dituntut untuk belajar dan berujung untuk meraih kemampuan dalam 'mengendalikan' masa depan. Belajar mengendalikan nasib sendiri mencakup mengembangkan kemampuan dan kecakapan untuk membangun masa depan yang lebih baik, masa depan yang mereka pilih sendiri, melakukan hal yang mereka rasa dan anggap sangat penting dan bermakna, yang mendatangkan manfaat bagi dirinya dan bagi orang lain juga bagi lingkungan sekitar. Ini berarti bahwa belajar haruslah lebih dari sekedar menguasai pengetahuan dan keterampilan yang berbasis pada kompetensi saja. Belajar seharusnya juga mencakup pembinaan kreativitas, pencerahan mengenai tujuan hidup, pembangunan rasa harga diri 
dan rasa mampu, memperjelas dan meningkatkan komitmen terhadap nilai-nilai luhur dan prinsip hidup yang bersifat universal, dan memupuk harmonisasi rasa kesalingketergantungan dengan sesama manusia. Ini berarti bahwa lebih banyak perhatian dan usaha yang perlu diberikan untuk pengembangan kecerdasan interpersonal dan intrapersonal.

\section{Kecerdasan intrapersonal} menyangkut kemampuan untuk memahami diri sendiri dengan baik - termasuk memahami hasrat, kecemasan, dan kemampuan diri sendiri - dan menggunakan pemahaman diri itu secara efektif untuk mengatur hidup. Kecerdasan interpersonal menunjukkan kemampuan seseorang untuk memahami niat, motivasi, dan hasrat orang lain, dan dengan sendirinya, kemampuan untuk bekerja sama secara efektif dengan orang lain. Kualitas mental yang berkaitan dengan kecerdasan intrapersonal adalah kesadaran akan tujuan hidup, harga diri, kemampuan diri, dan komitmen untuk berpegang pada nilai-nilai luhur tertentu. Kesadaran itu berfungsi sebagai penunjuk arah, pedoman, dan juga motivator bagi kehidupan seseorang. Kesadaran itu akan membantu seseorang dalam meminimumkan risiko tersesat di dalam lingkungan yang makin kompleks dan selalu berubah, dan menghindari kemungkinan bekerja keras seumur hidup untuk tidak menjadi siapasiapa.

$$
\text { Di sisi lain, rasa }
$$

kesalingtergantungan dalam relasi sosial membuat seseorang menaruh perhatian terhadap apa yang akan terjadi pada orang lain, suatu hal yang penting untuk membangun hubungan yang saling menghormati dan saling mempercayai. Semua ini akan menolong seseorang untuk mengatasi keberagaman, membina kerjasama kreatif, dan menyelesaikan konflik dengan damai. Ini adalah ranah kecerdasan interpersonal.

Pertanyaannya sekarang adalah: Dapatkah kita membuat proses belajar pada berbagai tingkatan pendidikan dapat lebih banyak menyumbang dalam mengembangkan kecerdasan intrapersonal dan interpersonal pada para peserta didiknya? Apa yang diperlukan agar pendidik dapat lebih berperan efektif dalam upaya ini? Semua pertanyaan itu mungkin tidak penting atau tidak relevan diajukan pada mereka yang tinggal di negara industri atau negara maju.

Faktanya, di Indonesia, tujuh puluh tahun lebih proklamasi kemerdekaan dideklarasikan, nampaknya pemerintah belum menemukan arah yang tepat dalam membangun pendidikan. Kurikulum pada berbagai level pendidikan berkali-kali 
diganti, tanpa diketahui dengan pasti apakah kurikulum yang sebelumnya sudah mencapai sasaran yang diharapkan atau tidak. Di lapisan akar rumput (grass roots) para dosen, kepala sekolah dan guru-guru kebingungan karena mereka harus melakukan sesuatu yang benar, sementara hal-hal yang mereka harus lakukan sebagai para pendidik menurut kurikulum lamapun belum mereka pahami sepenuhnya, apalagi yang baru.

Masalahnya menjadi semakin rumit di tengah-tengah proses globalisasi yang makin lama makin meluas dan makin intensif dewasa ini. Dunia menjadi tidak berbatas, informasi mengalir deras dengan bebas, demikian juga modal dan tenaga kerja tidak lagi dapat dibendung. Negeri atau orang dengan modal intelektual yang tinggi telah mendapatkan amat banyak kesempatan untuk menghasilkan kekayaan lebih banyak bagi diri mereka sendiri. Tetapi, negeri-negeri atau orang-orang yang tertinggal dalam pembangunan modal intelektual, dengan jejaring kerjasama yang amat terbatas, proses globalisasi cenderung membawa lebih banyak kebingungan dan kekacauan ketimbang mendatangkan kesempatan. Mereka hanya mendapat dampak negatif dari dunia yang tanpa batas, seperti krisis ekonomi, konflik sosial, kerusakan lingkungan, dan yang baru-baru ini 'teroris tanpa batas' bisa terjadi di mana saja, kapan saja. Mereka tersesat dan menjadi korban proses globalisasi (Raka, 2013).

'Control your destiny or someone else will', begitu bunyi judul sebuah buku; kendalikan nasib Anda, kalau tidak, orang lain yang akan mengendalikannya. Di dalam dunia yang tidak lagi berbatas dan berubah dengan cepat, makin banyak kemungkinan bagi seseorang untuk kehilangan kendali atas nasib atau masa depannya sendiri. Godaan untuk ikut dan larut dalam arus massa tak pelak lagi menjadi makin menarik. Banyak anak muda yang tumbuh untuk kemudian kehilangan jati diri. Yang sangat memprihatinkan, hanya sedikit di antara mereka yang menyadarinya. Para pendidik di berbagai level tingkatan pendidikan seharusnya memberikan lebih banyak perhatian dan usaha optimal untuk mengatasi masalah ini.

Pendidikan, sejatinya merupakan upaya mempersiapkan generasi selanjutnya. Artinya, amanah dari proses pendidikan adalah menciptakan generasi yang mampu mandiri dalam berpikir, bersikap dan berkarya. Sebab, generasi yang ada sekarang ini tidak mungkin selalu dapat mendampingi generasi selanjutnya. Suatu saat, generasi muda saat ini harus mampu untuk berdiri di atas kakinya sendiri. Artinya, kemandirian adalah warisan yang seharusnya dapat dijalankan 
oleh generasi mendatang, mengingat tantangan kehidupan yang semakin besar di kemudian hari (Wibowo, 2016).

Namun sayang, fenomenanya, ada banyak peserta didik potensial, yang 'dihancurkan' di bangku sekolah. Mereka tidak lagi dapat mengembangkan potensi mereka karena lingkungan belajarnya, baik psikologis maupun sosial, kurang tepat. Hal ini terjadi karena para pendidik tidak menyadari betapa dahsyat dan dalamnya pengaruh (lewat kata-kata, emosi, dan tindakan) yang mereka tanamkan di dalam pikiran dan kemudian muncul sebagai perilaku peserta didik.

Kelihatannya, untuk dapat merumuskan visi pribadi atau tujuan hidup diri sendiri serta menemukenali nilai-nilai luhur yang akan dipegang dan dijalankan dalam kehidupan, diperlukan proses belajar yang panjang. Proses belajar seperti ini harus memanfaatkan banyak rujukan. Konsep kita tentang kehidupan yang berhasil dan bermakna mungkin amat dipengaruhi oleh pengalaman dari peristiwa khusus yang terjadi dalam kehidupan, pengalaman hidup yang diperoleh dari lingkungan sosial tertentu. keyakinan yang bersumber dari spiritualitas yang tinggi, pemahaman yang mendalam tentang ketuhanan, belajar dari buku-buku yang kita baca, seperti biografi tentang seorang pahlawan atau orang terpandang, keberhasilan yang dicapai atau karakter dari tokoh yang kita kagumi, bahkan dari kearifan yang tersembunyi di dalam cerita rakyat atau mitologi dalam budaya tertentu.

Dari berbagai sumber tersebut, seseorang dapat memilih nilai atau prinsip tertentu yang dianggapnya paling baik atau mulia, dan menjadi dasar dalam merumuskan visi atau tujuan hidupnya. Kebanyakan dari kita mungkin tidak menyadari akan adanya proses belajar seperti ini. Semuanya berlangsung secara alamiah, dan tidak berstruktur, mengalir begitu saja tanpa kesadaran penuh. Kita tidak mempelajarinya seperti, misalnya, saat belajar matematika, di mana kita mempelajarinya dengan cara yang berbeda, dengan keseriusan dan kesadaran penuh, walaupun seringkali tidak berhasil kita pahami.

Inspirasi, idealisasi, refleksi, perenungan, pencerahan, metafora atau kiasan, interaksi sosial, dan semua itu sangat berperan penting dalam proses belajar ini. Kita menetapkan tujuan, kita bertekad berpegang teguh pada nilai luhur dan prinsip tertentu karena sifatnya yang sangat menggugah dan menyentuh hati kita. Dalam hal ini, belajar mencakup proses memilih dan memilah. Seseorang menetapkan tujuan hidupnya, atau menentukan cita-citanya, atau membangun visinya, atau mendahulukan nilai-nilai tertentu di antara pilihan-pilihan 
lain, semuanya sangat dipengaruhi oleh berbagai pengalaman dan pemahaman dari orang itu sendiri, yang hidup di dalam suatu lingkungan fisik, sosial, mental, emosional, dan spiritual tertentu.

Idealnya, peran pendidik (dosen) dalam hal ini lebih pada menciptakan lingkungan belajar yang menggugah ilham atau inspirasi, idealisme, memfasilitasi interaksi sosial yang positif dan memberikan banyak kesempatan kepada peserta didik (mahasiswa) untuk memprakarsai percobaan atau kegiatan yang secara bertahap akan memperkuat rasa percaya diri, harga diri, dan menambah kemampuan mereka untuk hidup bersama dengan serasi dan kreatif, di dalam masyarakat yang penuh kebhinekaan. Dalam banyak hal, dosen diharapkan berperan sebagai pemimpin transformasional, yang dapat mempengaruhi mahasiswa melalui penciptaan lingkungan belajar yang tepat. Lingkungan belajar ini hendaknya dapat mendukung interaksi dan memudahkan mahasiswa dalam melakukan usaha yang mereka arahkan sendiri untuk membangun dan menyalurkan potensi mereka menuju pencapaian tujuan yang bermakna.

Untuk menggugah inspirasi, idealisme dan membangkitkan rasa percaya diri dan harga diri mahasiswa, diperlukan dosen yang menginspirasi, percaya diri, mempunyai harga diri, dan menggunakan hatinya dalam memandu proses pembelajaran. Seperti halnya dengan semangat dan sikap optimis, yang bersifat menular, demikian juga inspirasi, rasa percaya diri dan harga diri. Di sini, dosen dapat meningkatkan kemampuan belajar dan motivasi mahasiswanya melalui sentuhan yang membesarkan hati, menumbuhkan kesadaran dan kepekaan rasa. Hal ini adalah gambaran suasana pembelajaran yang menyenangkan, menggembirakan, menggairahkan, dan membanggakan baik bagi diri dosen sendiri maupun bagi para mahasiswanya sehingga baik dosen maupun mahasiswa dapat samasama berprestasi dan mencapai tujuan yang bermakna.

Kemajuan dalam penguasaan teknologi yang ditunjukkan oleh beberapa negara tetangga di Asia, khususnya Asia Timur, dan keinginan Indonesia untuk mengejarnya, nampaknya telah menjadi salah satu faktor yang menyebabkan munculnya berbagai kebijakan yang mereduksi pendidikan menjadi pengembangan kompetensi. Lembaga pendidikan, seolah-olah menjadi 'pabrik' pengembangan kompetensi untuk menyiapkan 'sumber daya manusia'. Tanpa disadari, di samping mereduksi makna pendidikan, kegandrungan pada kompetensi ini juga mereduksi manusia menjadi hanya sebagai sumber daya, seperti sumber daya lainnya: bahan baku, mesin dan uang. Ketika manusia hanya dilihat sebagai sumber daya, 
maka dimensi lain yang ada pada diri manusia yang membuatnya menjadi insan yang utuh dan manusiawi, seperti kesadaran baru, karakter yang baik dan kuat, serta cita-cita yang luhur, kemudian dinomorduakan. Harus diakui, pengembangan kompetensi memang penting; tetapi orang-orang dengan kompetensi tinggi namun dengan karakter buruk, akan menjadi sumber masalah besar bagi suatu masyarakat atau bangsa.

Untuk dapat memulai perubahan, di samping harga diri, seseorang memerlukan perasaan bahwa ia mampu dan dapat mencapai impiannya. Di sini, dorongan dan apresiasi dapat berperan penting untuk memupuk pembinaan rasa mampu tersebut. Belajar bersama dalam kelompok yang anggota-anggotanya memiliki dorongan positif yang sama, dapat mempercepat proses penguatan rasa mampu tersebut. Belajar bersama menumbuhkan rasa optimis dan gairah di antara anggota kelompoknya, yang secara bertahap akan menghilangkan rasa ketidakberdayaan mereka. Di dalam kelompok belajar, dosen dan mahasiswa dapat belajar bersama melalui proyek kecil-kecil yang mereka gagas sendiri.

Kelompok belajar ini selanjutnya dapat menetapkan visi dan misi bersama, membayangkan gambaran tentang masa depan yang lebih baik bagi kelompok ini, dan menjabarkan hal-hal yang akan mereka lakukan dan berbagai kemungkinan cara untuk dapat mencapainya. Mereka menciptakan tata nilai atau prinsip-prinsip yang diyakini bersama. Di sini, proses belajar jauh lebih penting dari substansi pelajaran. Proses ini adalah proses pemberdayaan diri. Anggota kelompok perlahan-lahan mulai belajar mengendalikan nasib mereka sendiri. Prosesnya mengalir secara alami dan dalam kesadaran bersama.

Berkaca pada pemaparan di atas, hingga hari ini berbagai upaya perbaikan dan peningkatan terhadap kurikulum khususnya di Prodi Kesejahteraan Sosial FISIP Unpad terus dilakukan. Dimulai dari pembenahan paradigma pendidikan pekerjaan sosial, visi, misi, tujuan, susunan mata kuliah, metode pembelajaran, rencana pembelajaran, sistem praktikum, hingga orientasi kegiatan kemahasiswaan. Serta bagaimana pelibatan alumni dalam proses pendidikan pekerjaan sosial, sehingga menghubung-dekatkan (link and match) penciptaan dan pemenuhan dunia kerja dengan pendidikan. Terdapat tiga pilar utama yang menopang kemajuan pendidikan pekerjaan sosial, yaitu dosen, mahasiswa dan alumni kesejahteraan sosial. Dosen, sebagai salah satu pilar, merupakan faktor utama dan pertama yang mendorong self driving learning system (Raharjo, 2016). Harapannya, tentu saja tercipta sistem yang kondusif yang dapat menggerakkan dosen, mahasiswa dan juga 
alumni unuk sama-sama berpikir, bersikap dan berkarya sehingga proses pembelajaran melalui self driving learning system ini bukan hanya ditujukan untuk mencetak profil lulusan yang memiliki kompetensi, melainkan juga memiliki karakter yang positif.

\section{SIMPULAN}

Prinsip self driving learning system menuntut pergeseran mentalitas dari 'passenger' yang cenderung bersikap hanya menjadi penonton, pengamat, pengikut, pesorak, penggerutu, pemrotes; yang dari semua sikap tersebut tidak pernah berujung pada produk kinerja nyata; bahkan untuk dirinya sendiri. Bergeser menjadi 'driver', maka akan cenderung memiliki pandangan jauh (visi), yang sangat dituntut untuk merawat diri dan kendaraannya; yang selalu sigap siap sedia terhadap perubahan cepat yang terjadi; yang selalu meningkatkan pengetahuan, keterampilan dan meneguhkan sikap; yang peduli terhadap diri dan keselamatan penumpangnya; yang selalu berupaya mencapai tujuan dengan selamat sehat dan menyenangkan; yang produktif menghasilkan karya-karya kinerja sebagai rasa tanggung jawab diri, institusi dan maslahat bagi lingkungannya (Kasali, 2015). Tantangannya adalah, bagaimana menumbuh-kembangkan mentalitas tersebut dengan menyirami dan memberi pupuk agar tetap subur di hati manusia. Tentunya, untuk dapat mewujudkan harapan melalui self driving learning system ini dibutuhkan proses yang panjang, waktu yang tidak sebentar, perjuangan dan pengorbanan yang tidak sedikit. Dan kita sudah memulainya sekarang.

\section{Sumber Bacaan:}

Howard Gardner, Intelligence Reframed: Multiple Intelligences for the $21^{\text {st }}$ Century, Basic Books, 1999, h.43.

Raka, Gede, 2013, Jangan Memanjat Pohon Yang Salah, Masyarakat Pendidikan Sejati

Tichy, Noel M. \& Startford Sherman, 2001, Control your destiny or someone else will, Harper Collin Publisher.

Whibawa, dkk., 2016, Self Driving Learning System, Unpad Press. 